\author{
О. А. Шарыкина \\ Институт русского языка им. В. В. Виноградова РАН \\ (Россия, Москва) \\ oka.scalig@gmail.com
}

\title{
ОСОБЕННОСТИ ОПИСАНИЯ ФРАЗЕОЛОГИЗМОВ В «ТОЛКОВОМ СЛОВАРЕ РУССКОЙ РАЗГОВОРНОЙ РЕЧИ»
}

В статье рассказывается о том, как представлены фразеологизмы (фраземы) в «Толковом словаре русской разговорной речи» (под ред. Л.П. Крысина), каковы их лексико-грамматические особенности, с какими трудностями сталкиваются авторы словаря при описании таких единиц и как эти трудности преодолеваются. Статья состоит из двух основных частей. В первой подробно рассматриваются варианты представления фразем в словарной статье, основные принципы отнесения той или иной единицы в зону PHRAS и случаи указания дополнительных стилистических помет. Вторая часть посвящена описанию лексико-грамматических особенностей разговорных фразеологизмов: отмечается большая зависимость их значения от контекста (вводных определений, зависимых слов, управления и т.п.). Большое внимание уделяется появлению новых значений отдельных фразем в разговорной речи. Приводятся также примеры фразеологизмов, которые впервые описаны в рамках словаря. В заключение читателям предлагается оценить несколько вариантов употреблений фразеологизмов в современной разговорной речи и делается вывод о том, в каких случаях можно говорить о расширении значения фразеологизмов в данном типе коммуникации, а в каких речь идёт об ошибочном, некорректном употреблении фразеологических сочетаний.

Ключевые слова: фразеология, разговорная речь, семантика, грамматика, толковый словарь.

Употребление разного рода фразеологизмов, несомненно, является одной из отличительных черт разговорной речи. По данным первых трёх томов «Толкового словаря русской разговорной речи» (под ред. Л.П. Крысина' $\left.{ }^{1}\right)$, фраземы

1 Толковый словарь русской разговорной речи. Вып. 1: А - И. - М.: Языки славянской культуры, 2014; Толковый словарь русской разговорной речи. Вып. 2: К - О. - М.: Языки славянской культуры, 2017; Толковый словарь русской разговорной речи. Вып. 3: П - Р. - М.: Языки славянской культуры (в печати). 
(преимущественно идиомы и коллокации), функционирующие в устной и письменной разговорной речи, составляют едва ли не четверть от общего объёма всех словарных статей. Поскольку в качестве иллюстративных примеров в данном словаре использовались только современные тексты: художественная литератуpa, записи устной речи, интернет-издания и блоги конца XX - начала XXI в. можно говорить о том, что он отражает живое употребление фразеологических единиц.

Особенность описания фразеологизмов в указанном словаре прежде всего состоит в том, что в словарной статье они могут быть представлены как в зоне PHRAS, например:

\section{ГРЕШÓК.}

1. DEF: предосудительный поступок.

PHRAS: замаливать грешок - пытаться загладить, исправить плохой поступок. Получается, помогая вам, Алла Борисовна как бы замаливала старый грешок перед Земфирой? (Комсомольская правда, 26.04.2002); A вы, Тимофеевич, вспомните сколько раз жену обижали и бегали по соседкам, пора замаливать грешки и вам (АиФ, комментарии, 11.04.2012) ${ }^{2}$,

так и самостоятельной словарной статьёй, например:

ОРЕ́ШЕК: крепкий орешек - о ком-чём-л., плохо поддающемся, воздействию. Дело в том / что этот джентльмен/ мирно дремлющий на диване/ тот самый крепкий орешек/ который оказался не по зубам нашей контрразведке // (К/ф «Приключения Шерлока Холмса и доктора Ватсона...», 1986); Ecmь у меня в мыслишках думы о жениховстве.. но выбранный мною объект оказался крепким орешком. Не согласен ни жениться на мне, ни быть моим женихом; Эта задачка оказалась крепким орешком, никто не прислал правильного ответа (Блоги, $2013)^{3}$.

В тех случаях, когда фразеологизм трудно отнести к какому-л. значению заглавного слова или же значение фраземы с ним не пересекается, он даётся в зоне PHRAS в самом конце словарной статьи, ср.:

\section{КАКО́Й.}

1. DEF: никакой, совсем не. Да какой он реставратор!; Мне-то какая разница? (Записи устной речи, 2015).

2. DEF: какой-нибудь. Нет ли какой еды?

3. DEF: какой угодно, любой. Дело в том/ что хоть молодая аудитория хоть какая.../ нет приязненного интереса к узнаванию чего-то// (ТВ «Культура», «Школа злословия», Т. Толстая, 2003).

\footnotetext{
${ }^{2}$ Из словарной статьи, составленной Е. В. Какориной.

${ }^{3}$ Из словарной статьи, составленной О. А. Шарыкиной.
} 
PHRAS: Какой ещё?; Какой такой? - раздражённый вопрос при упоминании кого-л. или чего-. неизвестного. - Андрей принёс! - Какой ещё Андрей? - Настройщик! (К/ф «Настройщик», 2004) ${ }^{4}$.

B зоне PHRAS описываются также однословные единицы, которые, как правило, употребляются в составе относительно устойчивых сочетаний, напр.: завались чего (“очень много", ср.: Успею ещё, времени завались), <хоть> залейся ("о чём-л., имеющемся в большом количестве, в избытке”, ср.: А изветов у нас хоть залейся), класть на что («сознательно пренебрегать чем-л. серьёзным», ср.: - Где ты иляешься весь вечер/ завтра контрольная/ надо перерешать все задачи// - Да клал я на эти задачи//) и др.

Стилистические пометы сопровождают только те фраземы, которые помимо «разговорности» обладают какой-л. эмоционально-стилистической окраской, напр.: поставить всё с ног на голову (неодобр.), дело пахнет керосином (шутл.), дело за малым (часто ирон.), выпасть в осадок (жарг.), сиди и не мяукай! (сниж., груб.) и т.п.

Анализируя материал словаря, можно отметить следующие лексико-грамматические особенности разговорных фразем. Во-первых, большая зависимость значения от контекста: вводных определений, зависимых слов, управления и т. п., ср.:

Без ног - сильно устав после тяжелой работы, долгой ходьбы и т. п.

Без задних ног - 1) беспробудно, крепко (спать); Герой Советского союза полковник открывает нам дверь/ а его денщик сержант спит без задних ног// (К/ф «Анкор, ещё анкор», 1992); 2) сильно устав после тяжелой работы, долгой ходьбы и т. п. Работа цельй день, вечером валишься без задних ног (Комсомольская правда, 2011).

Не проносить мимо рта кусок, ложку - не упускать выгоду. Кривцов был ушльй мужик. ...И Тонька - баба не промах. Мимо рта ложку не пронесёт (А. Савельев. Аркан для букмекера).

Не проносить мимо рта рюмку - часто и много выпивать. У Шукшина герои рюмку мимо рта не проносят, да и не выпивии с чего бы им куролесить (М. Кураев. Записки беглого кинематографиста).

В четыре руки делать что - делать что-л. вдвоём. Стариие [дети] справляются быстро, а мальишам приходится помогать. Мы с мужем в четыре руки одеваем мальией (Комсомольская правда, 23.03.2013).

Играть в четыре руки - исполнять музыкальное произведение вдвоем на рояле, фортепьяно и т. П. К концу ужина все немного успокоились... и Юлия

\footnotetext{
${ }^{4}$ Из словарной статьи, составленной М. Я. Гловинской.

${ }^{5}$ Из словарной статьи, составленной Н.Н. Розановой.
} 
Михайловна с тётей Элли сели за пианино и играли в четыре руки (Ю. Трифонов. Дом на набережной) ${ }^{6}$.

Откуда ноги растут - ягодицы, зад. - Димон/ ну-ка перестань! А то сейчас получишь по одному месту// - По какому, дед? - По такому! Откуда ноги расmym/ вот по какому// (Запись устной речи, 2003).

Откуда ноги растут у чего - о том, что является главной причиной, первоисточником чего-л. Откуда ноги растут у всех этих новостей, непонятно (Интернет-издание «Полит-Грамота», 2016) ${ }^{7}$.

Во-вторых, у некоторых фразеологизмов в разговорной речи происходит расширение значений. Например, у выражений <держать> рот на замке, <закрыть> рот на замок («молчать, не разглашать тайну») появляется значение «не принимать пищу (с целью похудеть, соблюдая диету и т.п.)», ср.: - Как избавляетесь от лишнего веса? - Я просто перестаю есть вечером. После 18 часов рот на замок (Амурская правда, 2018). А идиома на ноги поставить <поднять> может употребляться не только по отношению к одушевлённым предметам (в значениях «вылечить, сделать здоровым кого-л.»; «вырастив и воспитав, подготовить к самостоятельной жизни кого-л.», «заставить активно действовать, принять неотложные меры для достижения какой-л. цели»), но и к неживым объектам - в значении «сделать успешным какое-л. предприятие, учреждение, хозяйство и т. п.», ср.: На такое дело надо ставить только молодого/ чтобы он успел что-то сделать за свою жизнь// То есть молодёжь/ те/ кто будут развивать усадьбу дальше/ те/ кто будут дальше её ставить на ноги// (Д/ф «Письма из провинции»/ Т/к «Культура», 2008).

Зачастую выделение нового значения связано с некоторыми трудностями. Чтобы продемонстрировать, в чём они заключаются, предлагаю Вам почувствовать себя автором «Толкового словаря русской разговорной речи», которому предстоит включить (или не включить) в словарь приведенные ниже примеры

1. В Норвегии нет пожизненного заключения. Отсидел 20-30 лет - и свободен как банный лист.

2. Звоните главному инженеру вамего района и требуйте, чтобь он поставил на ноги лежебок-дворников.

3. Моделям плюс сайз непросто - в крупном весе сложнее следить за собой. Им нужно держать себя в ежовых рукавицах, чтобы сохранять рельеф кожи гладким.

4. Самым общцительным знаком зодиака считаются Весы. Им палец в рот не клади - дай только поболтать часок другой.

\footnotetext{
${ }^{6}$ Из словарной статьи, составленной О.А. Шарыкиной.

${ }^{7}$ Из словарной статьи, составленной Н.Н. Розановой.

8 Данные примеры взяты преимущественно из газет 2012 и 2018 годов издания.
} 
5. Организаторы свадебньх торжеств лезут из кожи, как цуаревна-лягушка для того, чтобь этот день запомнили на всю жизнь не только молодожёны, но и их родители, гости, друзья.

Данные примеры, на наш взгляд, наглядно отражают не только уровень владения фразеологией носителей языка, но и особенности работы лексикографа: уметь отсеивать то, что является единичным, индивидуальным употреблением фразеологизма или же вовсе неправильным, и увидеть те случаи, когда у фраземы действительно появляется новый оттенок значения. Так, в примере (1) выражение <пристать> как банный лист употреблено неверно, поскольку оно имеет значение «настойчиво приставать к кому-л.». В данном контексте стоило бы использовать фразему свободен как ветер. Подобного рода ошибка допущена и в примере (4): вместо фразеологизма палец в рот не клади кому (имеющего два значения: 1) о том, кто не упустит случая использовать кого-что-л. в своих интереcax; 2) о том, кто может постоять за себя) должен был быть хлебом не корми кого. Пример (5) с фразеологическим оборотом лезть из кожи <вон> («очень стараться») неудачен отсылкой к русской народной сказке «Царевна-лягушка». Согласно сюжету лягушка сбросила кожу, не прилагая особых усилий (правда, последствия этого поступка были, как известно, плачевными). Не слишком удачным следует признать и пример (3): здесь уместнее было бы употребить выражение держать себя в руках - контаминация двух фразем: держать себя в руках и ежовые рукавицы породило нелепицу. На наш взгляд, допустимым является только пример (2), в котором использовано многозначное выражение на ноги поставить <поднять $>$ 9, благодаря чему достигается эффект языковой игры.

В заключение стоит отметить, что в «Толковом словаре русской разговорной речи» впервые зафиксированы и истолкованы некоторые фразеологические выражения, например: включить (включать) голову - 1) подумать (думать) над чем-л; осознанно, и разумно отнестись (относиться) к чему-л.; 2) включить внимание, сосредоточиться на чём-л.; упереться рогом - проявить упрямство, настоять на своём (как правило, отказавшись делать что-л.); крутой замес - о чём-л., поражающем воображение или вызывающем негодование, и многие другие.

\section{Литература}

ТСРР-1 - Толковый словарь русской разговорной речи. Вып. 1, А - И / Под ред. Л.П. Крысина. М. : Языки славянской культуры, 2014. 776 с.

ТСРР-2 - Толковый словарь русской разговорной речи. Вып. $2, \mathrm{~K}$ - О / Под ред. Л.П. Крысина. М. : Языки славянской культуры, 2017. 864 с.

${ }^{9}$ На ноги поставить <поднять > - 1) вылечить, сделать здоровым; 2) вырастив и воспитав, подготовить к самостоятельной жизни; 3) заставить активно действовать, принять неотложные меры для достижения какой-л. цели; 4) сделать успешным какое-л. предприятие, учреждение, хозяйство и т.п. 
ТСРР-3 - Толковый словарь русской разговорной речи. Вып. 3, П - Р / Под ред. Л.П. Крысина М. : Языки славянской культуры, 2019. 824 с.

\author{
O. A. Sharykina \\ V.V. Vinogradov Russian Language Institute (Russian Academy of Sciences) \\ (Moscow, Russia) \\ oka.scalig@gmail.com
}

\title{
SOME ASPECTS OF THE DESCRIPTION OF IDIOMES IN "EXPLANATORY DICTIONARY OF THE RUSSIAN EVERYDAY SPEECH”
}

This paper deals with the representation of idioms in "Explanatory dictionary of the Russian everyday speech" (ed. L.P. Krysin), their lexical-grammar features, the difficulties with which the authors of the dictionary are faced and how they are overcome.

The article consists of two parts. In the first part the variants of representation of idioms in the lexical entry, the main principles of attribution of the unit to the zone PHRAS and examples of noting additional stylistic marks are considered in details. The second part is devoted to description of the lexical-grammar features of the colloquial idioms. Their greater dependence on the context (parentheses, dependent words, government, etc.) is mentioned. A lot of attention is paid to the new meanings of some idioms in the colloquial speech. The examples of the idioms, described for the first time in the above-noted dictionary, are given as examples. In conclusion the readers are suggested to estimate some variants of usage of the idioms in the modern colloquial speech. It is concluded about when we can speak of meaning extension in this type of communication and when it is a case of the incorrect usage of idioms.

Keywords: phraseology, colloquial speech, semantics, grammar, explanatory dictionary.

\section{References}

Tolkovyy slovar' russkoy razgovornoy rechi Pod red. L.P. Krysina [The Explanatory Dictionary of Russian Everyday Speech (ed. by L.P. Krysin)], issue 1, Moscow, Yazyki slavyanskoy kul'tury Publ., 2014. 776 p.

Tolkovyy slovar' russkoy razgovornoy rechi Pod red. L.P. Krysina [The Explanatory Dictionary of Russian Everyday Speech (ed. by L.P. Krysin)], the issue 2, Moscow, Yazyki slavyanskoy kul'tury Publ., 2017. 864 p.

Tolkovyy slovar' russkoy razgovornoy rechi Pod red. L. P. Krysina [The Explanatory Dictionary of Russian Everyday Speech (ed. by L.P. Krysin)], the issue 3, Moscow, Yazyki slavyanskoy kul'tury Publ., 2019. 824 p. 